\title{
Lotus (Nelumbo nucifera) - An Exploration of Hygro waste for Textile Applications
}

\section{Madhu Sharan ${ }^{1 *}$ and Sumi Haldar ${ }^{2}$}

${ }^{1}$ Professor, Guide and Head, Department of Clothing and Textiles, Faculty of Family and Community Sciences, The Maharaja Sayajirao University of Baroda, India ${ }^{2}$ Research Scholar, Department of Clothing and Textiles, Faculty of Family and Community Sciences, The Maharaja Sayajirao University of Baroda, India

*Corresponding Author: Madhu Sharan, Professor, Head, Department of Clothing and Textiles, Faculty of Family and Community Sciences, The Maharaja Sayajirao University of Baroda, India.
Received: April 19, 2021

Published: April 30, 2021

(C) All rights are reserved by Madhu Sharan and Sumi Haldar.

\begin{abstract}
Lotus (Nelumbo nucifera.) an aquatic perennial plant cultivated widely from Kashmir to Kanyakumari. This species is a national flower of India and Vietnam. Due to the huge economic importance of flower, the cultivators cut the flower with the little length of the petioles leaving the rest entire as a "waste". The Petiole is a part between the flower and underground rhizome of the lotus plant. Petiole contains two types of xylem cells: tracheids and vessels. Several individual precious lotus fibers are orderly assembled in tracheids and vessels in the form of "Helix". There was no source of the Lotus fibers in India. So, the research was planned to explore this hygro- waste for textile use which includes right from the base to find out the availability of wetlands near and around Vadodara region of Gujarat, contacting the peoples associated with lotus cultivation, extraction of fibers, spinning of the yarn and preparation of handloom fabric. Results indicated feasibility for its use in textiles because all fibers cannot be a textile fiber it should have a good length, excellent strength, moisture absorbency and cohesiveness to convert into yarn and woven fabric. Testing of all essential properties of the fibers shows its feasibility for the application in textiles. Small scale industry can be developed by providing training regarding the extraction process of fiber, spinning and weaving which will assist the skill development and income generation to the rural communities and as well value-added products can be developed which can cater the market. Raw material to end product consists of no use of chemicals which saves the mother earth.
\end{abstract}

Keywords: Wetland; Lotus; Petiole; Textile Fiber and Yarn

\section{Introduction}

India is a country with a wetland eco-system. Wetlands are defined as land transitional between terrestrial and aquatic ecosystem where the water table is usually at or near the surface of the land is covered by shallow water [1]. There are major and minor plant resources harvested from the wetlands of rural India. A significant number of wetland plants can be considered as a bio resources [2]. One such aquatic plant is Lotus (Nelumbo nucifera). It is an aquatic perennial herbaceous plant. It is important horticultural plant with its uses ranging from ornamental, nutritional and medicinal values [3]. There are many species of lotus but in the research review it is reported that fibers of this particular species that is Nelumbo nucifera lotus submerged in the water are perfect to produce strong and durable fiber [4]. This fiber - producing species of the lotus is globally distributed from in Bhutan, China, Indonesia (Java), Japan, Korea, Malaysia, Nepal, New Guinea, Pakistan, Philippines, Russia, Srilanka, Thailand, Australia and America. In India it is native to Himalayan lakes, Assam, Kashmir, Madhya Pradesh, Manipur, Odisha, Rajasthan, Tamil Nadu, Uttar Pradesh, Maharashtra, Karnataka, Mysore and Kerala [5]. It is reported that some wetlands of central Gujarat like Ahmedabad, Kheda, Anand, Vadodara districts) and south Gujarat (Valsad and Navsari districts) have a impressive growth of lotus plants [6]. The plant requires humid-temperate to tropical climates, wetland habitats, flood plains, ponds, lakes, pools, lagoons, marshes, swamps and the backwaters of reservoirs. The plant grows up to about 1.5 meters in height and up to 3 meters in horizontal length. Its roots stay fixed inside the muddy base of the water bodies and the average leaf in diameter 
is about $60 \mathrm{~cm}$ glide over the surface of the water. Flowers are capable of growing up to $20 \mathrm{~cm}$ in diameter. The seeds are about $1 \mathrm{~cm}$ in diameter and 1.2- $1.8 \mathrm{~cm}$ in length and are housed in the woody receptacle which looks like a shower head. The lotus plant grows by spreading a creeping rhizome at the bottom of the water body over anaerobic sediments. Rhizomes bear nodes, which produces leaf [7]. The morphological diagram of the lotus plant is shown in figure $1[8]$.

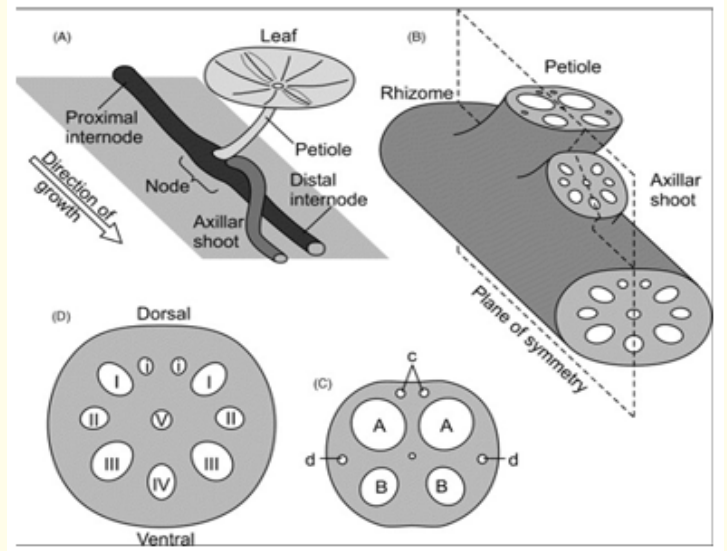

Figure 1: Morphological Diagram of Lotus (Nelumbo nucifera.). Link: https://www.semanticscholar.org/paper/Anatomy-ofthe-gas-canal-system-of-Nelumbo-nucifera-Matthews-Seymour/e9eed4ff374adb7b8ae237b728a46e6ba13aa9c2.

Lotus is an important and popular cash crop widely cultivated in many Asian countries, primarily because of its high edible and medicinal values derived from leaves, seeds and rhizomes. The lotus flower popularly known in Hindi by "Kamal ka phool" is one of those flowers that are acceptable to all the gods for worship [19]. After harvesting, a large amount of lotus petiole are normally generated as a waste and abandoned for the natural decay. Such waste may cause environmental degradation [20]. To explore this Hygro waste in textiles researcher started the study from the base that is visited lotus lakes, contacted lotus vendors, cultivators and wholesalers near and around the Vadodara region of the Gujarat. The main reason behind studying from the base is there was no sourcing for lotus fiber in India, for its use in textiles we need to know the amount of waste that can be procured, awareness given to the lotus cultivators for providing this waste as when required.

\section{Materials and Methods}

The Study was exploratory and experimental in nature.

\section{Collection of the lotus petiole}

Initially few petiole samples were collected from the vendors of the lotus flower from the Khanderao market of Gujarat. Bulk quan- tity was collected from the cultivators of Lotus near and around Vadodara region of Gujarat.

Availability of lotus petiole waste petiole waste near and around Vadodara district

To know the yield of lotus petiole waste, researcher contacted the vendors and cultivators of lotus who further helped to visit the pond locations near and around Vadodara district of Gujarat.

\section{Extraction of fibers}

The first and foremost step is to wash the petioles in the running tap water to remove all the dirt. Then the petioles are wiped with the fresh cloth. Bunch of three petioles were taken together at a time it was slited 3-5 times as the length of petiole. After one slit the petioles are slowly stretched apart to extract the fibers. Extracted Fibers were laid on the wooden slab. To make a continuous filament length the end -to -end points were joined by palm twisting and winded on the pern.

\section{Testing of fibers}

Physical properties of fibers

Fiber length

To determine the length of lotus fiber, the fiber was first placed against the dark surface and the length was measured with the steel ruler and repeated 50 times.

- Fiber Diameter: A Compound microscope with a micrometer lens was used to measure the fiber diameter. An average of 50 readings was taken to determine the fiber diameter.

- $\quad$ Fiber Fineness: Following ASTM D 7025 standard [9]. fiber fineness was tested. In the direct system of yarn numbering, Denier was determined by taking the average weight of 20 readings of $80 \mathrm{~cm}$ length of the fiber and calculations was done by using the formula.

Denier $=\underline{\mathrm{WX}}$

$\mathrm{L}$

Where,

$\mathrm{W}=$ Weight of the fiber

$\mathrm{L}=$ Length of the sample

$l=$ unit length of the system

\section{Fiber strength}

Following ASTM D 3822 [10]. standard, single fibre strength was tested. LLOYD tensile testing instrument was used for the evaluation. The sample length was $10 \mathrm{~cm}$. The instrument worked on a constant rate of elongation principle (CRE). The capacity of the instrument was $2500 \mathrm{~N}$. Pulling speed was $100 \mathrm{~mm} / \mathrm{min}$. The test was carried out in the Department of Textile Engineering, Faculty 
of Technology and Engineering, The Maharaja Sayajirao University of Baroda, Vadodara.

\section{Fiber moisture}

The amount of moisture in a sample of material is expressed in terms of Regain or Moisture Content. Regain is defined as weight of water in a material expressed as a percentage of the oven dried weight. Moisture Content is the weight of water in a material expressed as a percentage of total weight [11].

To determine the moisture content and regain, fibers of $10 \mathrm{gm}$ were weighted initially because fibers has some inherent moisture and then it was kept in oven for 4 hours. After 4 hours, the samples were taken out from the oven and weighted. Both moisture content and regain were calculated using formula: [11].

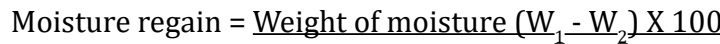
Oven dry weight $\left(\mathrm{W}_{2}\right)$

Moisture content $=\underline{\text { Weight of moisture }\left(\mathrm{W}_{1}-\mathrm{W}_{2}\right) \times 100}$

Sample weight $\left(\mathrm{W}_{1}\right)$

\section{Preparation of yarn}

Extracted Fibers were spun using traditional spinning system on peti (Charkha). The spinning of the yarn was done by Mr. Bakul Shah at Sardar Bhavan Trust and Khadi Emporium Vadodara, Gujarat.

\section{Construction of the fabric}

$100 \%$ Lotus fabric was prepared on a bead loom. Union fabrics were prepared on handloom using $100 \%$ Silk as a warp and lotus as a weft. Weaving was done at Bhujodi (Kutch) on handloom by Pachan Premji, Artisian Designer.

\section{Results and Discussion}

\section{Collection of lotus petiole}

For the procurement of the lotus petiole, vendors and cultivators of lotus around and nearby Vadodara district were contacted. Details of cultivators and vendors are mentioned in the (Figure 5).

Figure 5 List of peoples associated with Lotus cultivation and Marketing near and around Vadodara district of Gujarat.

Initially few petioles were procured from vendor Shantaben Mali. Due to the cost and small quantity at a time the cultivators were further contacted. Finally for the study, the petioles were procured from cultivator Poonambhai Parmar and Sanjaybhai Mali due to the good yield of lotus in there pond on daily basis and easy communication with them.

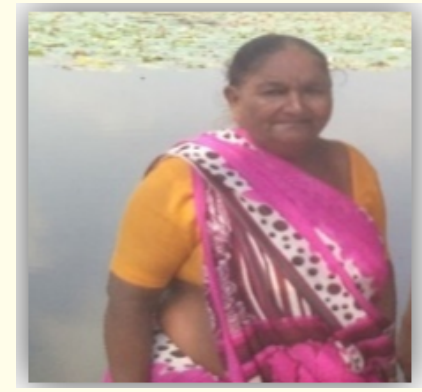

Figure 2: Shantaben Mali Vendor.

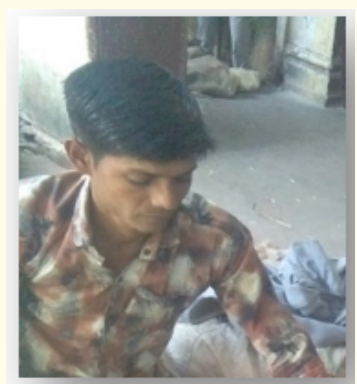

Figure 3: Sanjaybhai Mali Cultivator.

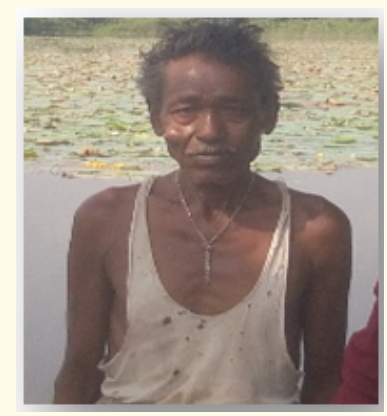

Figure 4: Poonam bhai Parmar Cultivator.

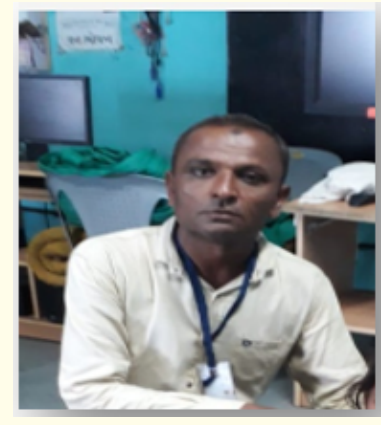

Figure 5: Isabbhai Rathod Cultivator. 
Availability of lotus petiole waste near and around Vadodara District

The place where the lotus grows is called wetlands. Wetlands include fresh water ponds, lakes, marshes, swamps and the backwater of the reservoir. Based on the yield of the lotus flower, these are the list of six places where the lotus grows near and around Vadodara district:

- $\quad$ Ganeshpur Village (8 Km far away from NH-8 highway) (Figure 6)

- $\quad$ Savli Taluka (Figure 7)

- $\quad$ Kamlapura Village, Near Parul College, Waghodia Road (Near National Highway No.8) (Figure 8)

- $\quad$ Kamlapura Village (Figure 9)

- $\quad$ Ruvad (Figure 10)

- $\quad$ Tarsali (Figure 11)

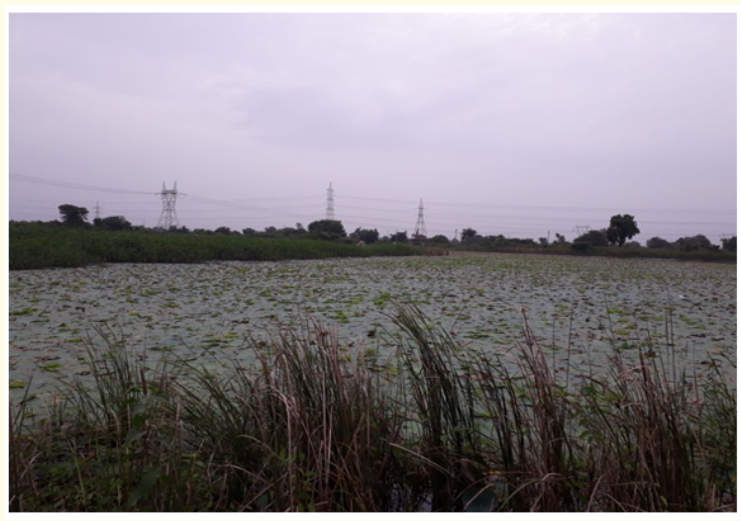

Figure 6: Ganeshpur Village, Vadodara.

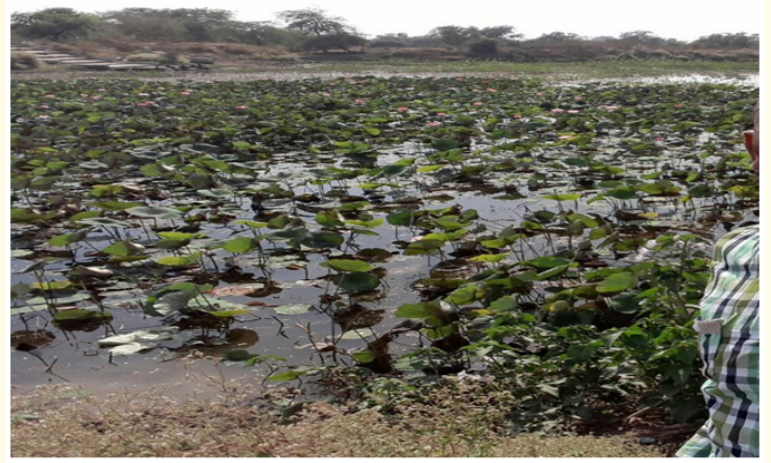

Figure 7: Savli Taluka, Vadodara.

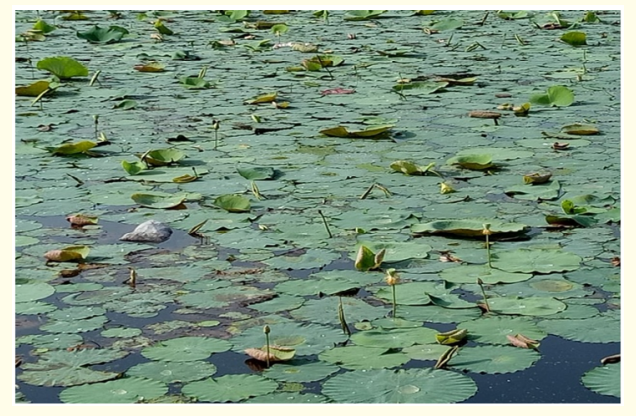

Figure 8: Kamlapura, Near Parul College Waghodia road, Vadodara.

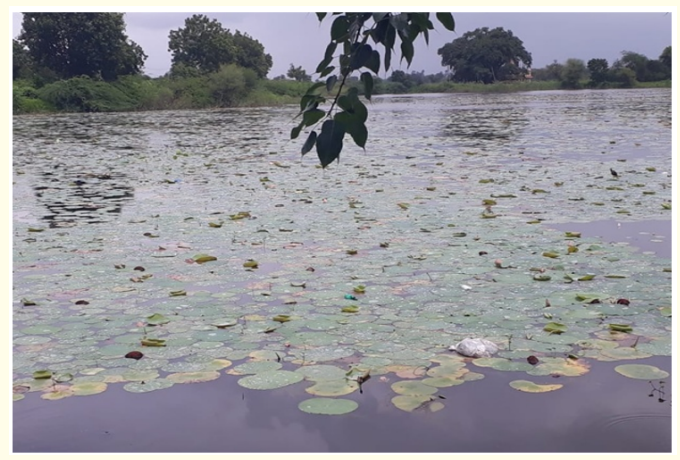

Figure 9: Ruvad, Vadodara.

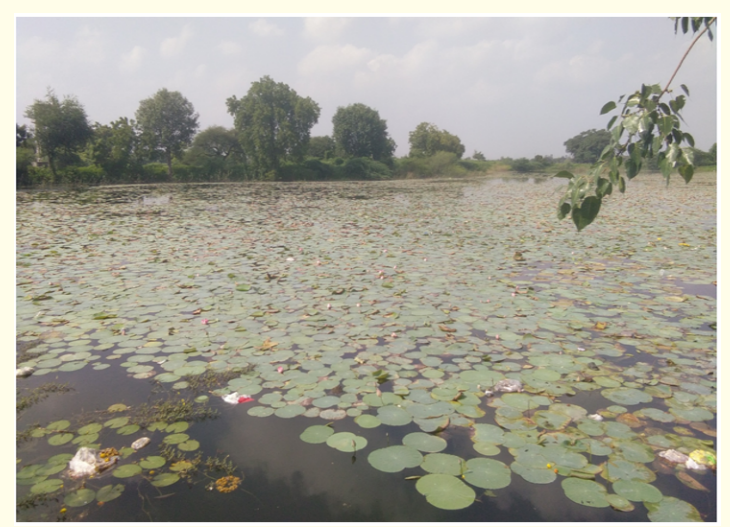

Figure 10: Tarsali, Vadodara.

\section{Extraction of fibers}

The flowchart of fiber extraction is mentioned in (Figure 12). 


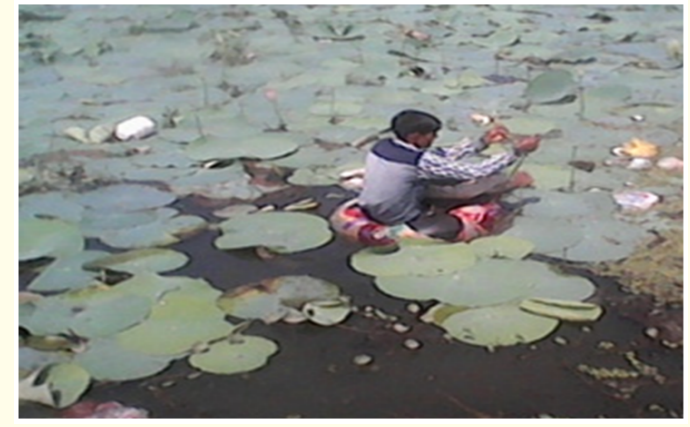

Figure 11: Kamlapura, Vadodara.
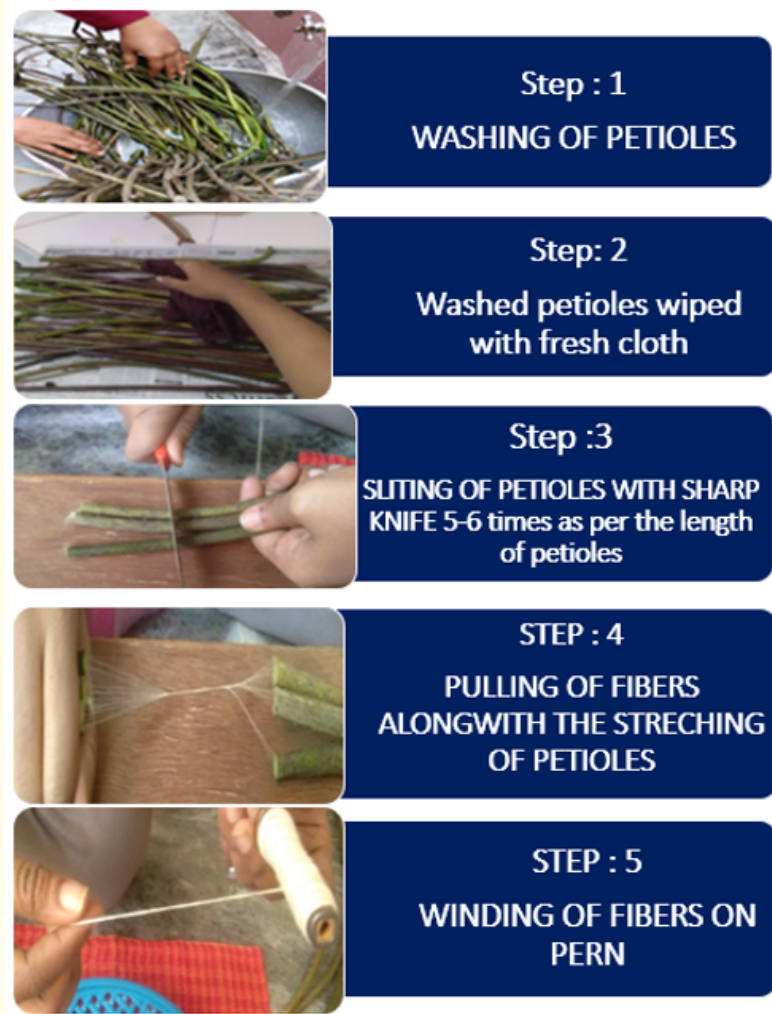

Figure 12: Process flowchart for Lotus Fiber Extraction.

Testing of fibers

Fiber length

The length of the lotus fibre was recorded between 60 to $105 \mathrm{~cm}$ and the average length was $80.70 \mathrm{~cm}$. Hence it has enough length to be twisted and converted into a yarn structure [12].

Fiber diameter

The diameter of the lotus fiber is shown in the table: Hence it indicates that lotus fiber is too delicate for ready conversion into yarn structure [12]. The diameter of the different protein fibers and plant fibers is shown in table 1 [13-15]. It indicates that the lotus fiber is very much finer than all other plant fibers. The Diameter is similar to silk fibers [13]. A small diameter of a fibre produces 'finer' fibers with greater pliability, flexibility and softness. Thus the fabric produced from lotus fiber will have a softer hand (i.e. feel) and drape (the way a fabric hangs) [16].

\begin{tabular}{|l|c|c|}
\hline Fiber & Diameter (Range) & Average \\
\hline Lotus Fiber & $2-6$ & 3.5 \\
\hline
\end{tabular}

Table 1: Diameter of Lotus Fiber.

\begin{tabular}{|c|c|c|c|c|c|}
\hline $\begin{array}{l}\text { Sr. } \\
\text { No. }\end{array}$ & $\begin{array}{c}\text { Protein } \\
\text { Fibers }\end{array}$ & $\begin{array}{c}\text { Diameter } \\
(\mu \mathrm{m})\end{array}$ & $\begin{array}{l}\text { Sr. } \\
\text { No. }\end{array}$ & $\begin{array}{c}\text { Plant } \\
\text { Fibers }\end{array}$ & $\begin{array}{c}\text { Diameter ( } \\
\mu \mathrm{m})\end{array}$ \\
\hline 1 & Silk & $5-10 \mu \mathrm{m}$ & 1 & Cotton & $14-21 \mu \mathrm{m}$ \\
\hline 2 & Vicuna & $6-10 \mu \mathrm{m}$ & 2 & Flax & $17-21 \mu \mathrm{m}$ \\
\hline 3 & Suri Alpaca & $10-15 \mu \mathrm{m}$ & 3 & Hemp & $15-30 \mu \mathrm{m}$ \\
\hline 4 & Qiviut & $11-13 \mu \mathrm{m}$ & 4 & Jute & $14-20 \mu \mathrm{m}$ \\
\hline 5 & Pashmina & $11-14 \mu \mathrm{m}$ & 5 & Sisal & $7-47 \mu \mathrm{m}$ \\
\hline 6 & $\begin{array}{c}\text { Merino } \\
\text { Wool }\end{array}$ & $12-20 \mu \mathrm{m}$ & 6 & Abaca & $10-30 \mu \mathrm{m}$ \\
\hline 7 & Angora & $13 \mu \mathrm{m}$ & 7 & Coir & $7-30 \mu \mathrm{m}$ \\
\hline 8 & Cashmere & $15-19 \mu \mathrm{m}$ & 8 & Pineapple & $25-30 \mu \mathrm{m}$ \\
\hline 9 & Yak & $15-19 \mu \mathrm{m}$ & 9 & Kapok & $15-43 \mu \mathrm{m}$ \\
\hline 10 & Guanaco & $16-18 \mu \mathrm{m}$ & 10 & Nettle & $20-80 \mu \mathrm{m}$ \\
\hline 11 & Camel & $16-25 \mu \mathrm{m}$ & 11 & Kenaf & $13-33 \mu \mathrm{m}$ \\
\hline 12 & Bison & $18.5 \mu \mathrm{m}$ & 12 & $\begin{array}{l}\text { Sansevie- } \\
\text { ria }\end{array}$ & $13-40 \mu \mathrm{m}$ \\
\hline 13 & $\begin{array}{l}\text { Tapada } \\
\text { Llama }\end{array}$ & $20-30 \mu \mathrm{m}$ & 13 & Ramie & $16-120 \mu \mathrm{m}$ \\
\hline 14 & Mohair & $25-35 \mu \mathrm{m}$ & 14 & $\begin{array}{l}\text { Hen- } \\
\text { equen }\end{array}$ & $8.3-33.2 \mu \mathrm{m}$ \\
\hline 15 & $\begin{array}{l}\text { Huacaya } \\
\text { Alpaca }\end{array}$ & $27.7 \mu \mathrm{m}$ & 15 & Mauritius & $15-32 \mu \mathrm{m}$ \\
\hline
\end{tabular}

Table 2: Diameter of natural protein and plant fibers.

Link: https://www.knittingthenaturalway.com/fiber-diameters https://www.textileschool.com/390/properties-of-vegetableplant-cellulosic-fibres/

https://dnfi.org/wp-content/uploads/2012/01/fact-sheet-plantfibers.pdf

\section{Fiber fineness}

Denier of the lotus fiber was 32 D. As per the direct system lower the denier finer the fiber and higher the denier coarser the fiber. Fiber fineness has a great influence on the properties of both yarn and fabrics. Hence the lotus fiber is very smooth and fine which will be useful to spin fine yarn. These characteristics will contribute to the superior hand feel of the fabric developed from lotus fiber.

\section{Single fiber strength}

Load and elongation, stress and \% strain values of lotus fiber were tabulated in table 3 . An average of 10 readings was taken.

Hence the lotus fiber has a poor elongation property. 


\begin{tabular}{|l|c|c|c|c|}
\hline $\begin{array}{l}\text { Fiber } \\
\text { sample }\end{array}$ & $\begin{array}{c}\text { Maximum } \\
\text { load (gf) }\end{array}$ & $\begin{array}{c}\text { Extension at } \\
\text { maximum (mm) }\end{array}$ & $\begin{array}{c}\text { Stress } \\
\text { gm/den }\end{array}$ & $\begin{array}{c}\text { Strain } \\
\text { (\%) }\end{array}$ \\
\hline $\begin{array}{l}\text { Lotus } \\
\text { fiber }\end{array}$ & 161.52 & 1.5589 & 5.0476 & 1.5589 \\
\hline
\end{tabular}

Table 3: Single fiber strength of Lotus fiber.

\section{Fiber moisture}

Most fibers tend to absorb moisture (water vapour) when in contact with the atmosphere. The amount of water absorbed by the textile fibre will depend on the chemical and physical structure and properties of the fibre, as well as the temperature and humidity of the surroundings. Fibres with good moisture regain and moisture content will accept dyes and chemicals more readily than fibers with low regain. A few of the textile fibers have very low regain and hence, it creates problems of static electricity during processing. Fibres with high regains will be easier to process, finish, and dye in aqueous solutions. Fibres with high regains are often desirable because they provide a "breathable" fabric that can conduct moisture from the body to the outside atmosphere readily, due to their favourable moisture absorption-desorption properties [16]. The moisture Content and regain of the lotus fiber is shown in table 4. The moisture regain values of some natural and regenerated textile fiber is shown in table 5 [17].

\begin{tabular}{|l|l|l|}
\hline Fiber & Moisture Content (\%) & Moisture Regain (\%) \\
\hline Lotus & 10.6 & 11.8 \\
\hline
\end{tabular}

Table 4: Moisture content and regain of Lotus fiber.

\begin{tabular}{|l|c|c|}
\hline Sr. No & Fiber & Moisture Regain (\%) \\
\hline 1 & Cotton (Raw) & 8.0 \\
\hline 2 & Cotton (Mercerized) & 8.5 \\
\hline 3 & Flax & 12.0 \\
\hline 4 & Hemp & 12.0 \\
\hline 5 & Jute & 13.75 \\
\hline 6 & Ramie (raw) & 7.5 \\
\hline 7 & Ramie (Scoured) & 7.8 \\
\hline 8 & Silk & 11.0 \\
\hline 9 & Wool & 13.6 \\
\hline 10 & Rayon & 11.0 \\
\hline
\end{tabular}

Table 5: Moisture regain of natural and regenerated fibers.

Source: ASTM D 1909-04 (1961) Standard Table of Commercial Moisture Regains for Textile Fibers1 West Conshohocken, PA

Moisture regain value of the lotus fiber was more than cotton and near to silk and viscose fibers.

Yarn preparation

Yarn is an assembly of fibers twisted together to form a continu- ous strand that is suited for the process of fabric manufacture [17]. The extracted fibers were spun into yarn on Box (Peti) charkha/ Foldable spinning wheel. It is a manual hand-driven charkha used for spinning cotton fibers.

To make a good quality yarn, it is important that the fibers must be similar in length and width as the uniformity of the input materials will give good quality yarn as output both in spinning quality and in flexibility [17].

It was observed that fibers were easily spinnable due to the inherent superior cohesiveness property of fiber, good length and fine diameter. The spinned yarn was smooth and uniform.

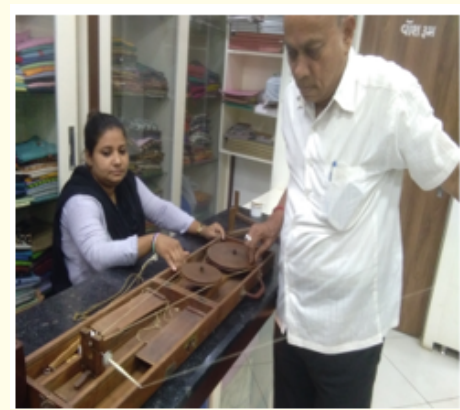

Figure 13: Spinning of Lotus yarn, Khadi Emporium, Vadodara.

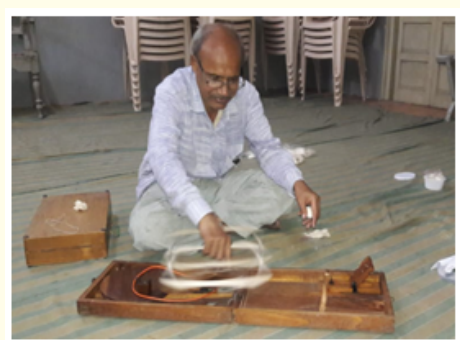

Figure 14: Spinning of Lotus yarn, Sardar Bhavan Trust, Vadodara.

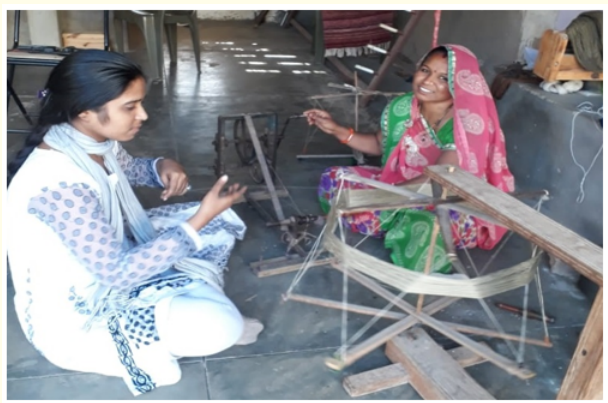

Figure 15: 100\% Lotus Handspun Yarn. 


\section{Construction of fabric}

Weaving is one of the basic methods of fabric construction. $100 \%$ Lotus both warp and weft was prepared on a Bead loom (Figure 16). It was observed that lotus fiber has a silk like appearance so further the fabric with silk as a warp and lotus as weft was prepared (Figure 17). As per the visual analysis and hand feel, the $100 \%$ lotus warp and weft fabric has a compact and soft appearance and lotus: Silk fabric has a sheer appearance like a net fabric.
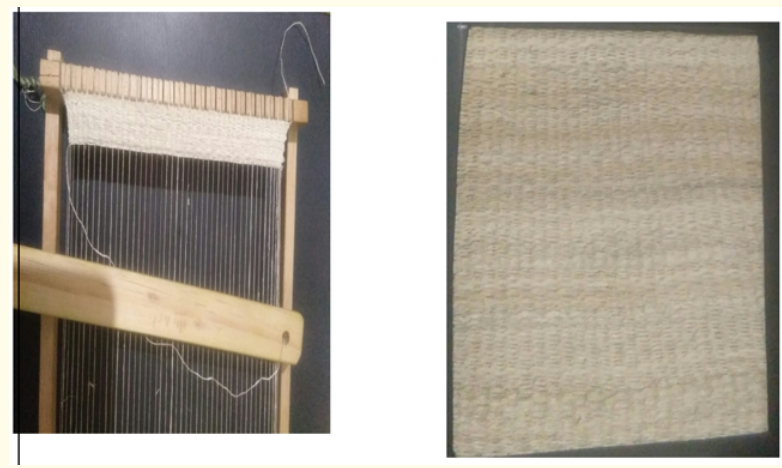

Figure 16: 100\% Lotus fabric on Bead Loom.

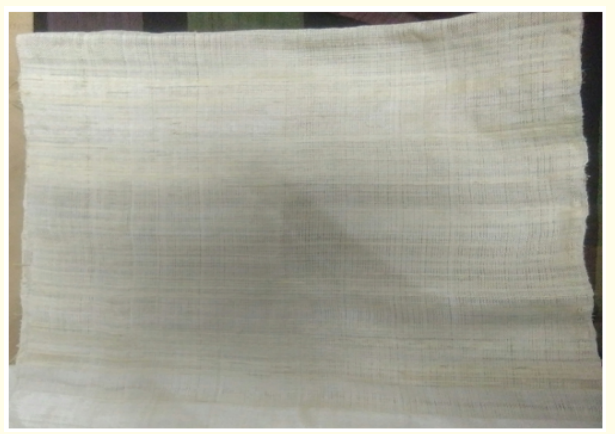

Figure 17: Lotus: Silk Hand-woven fabric.

Hence the fabric made from lotus fiber has a great potential to cater for the market due to its encouraging properties like superior fineness, higher moisture regains, natural luster and soft hand.

\section{Conclusion}

The textile industry is $2^{\text {nd }}$ largest polluting industry in the world. Thousands of toxic chemicals and water are used in the manufacturing of textiles which leads to global warming and depletion of the ozone layer. We all have observed that how our mother earth is healing in the Co-Vid pandemic. Nowadays right from small to large scale textile industry is finding the sustainable process for manufacturing. Ecofriendly fiber means the production process that has a low impact on the environment and should meet the criteria shown in figure 18.

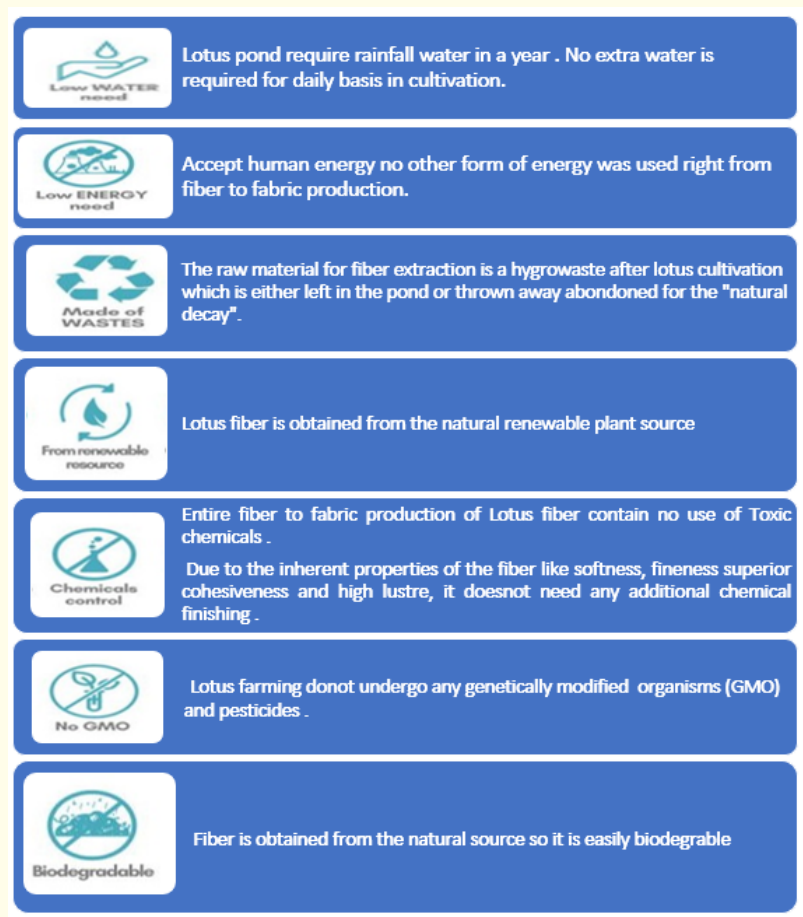

Figure 18: Criteria for the Eco-fibers.

The First and Foremost goal of Sustainable Development Goals (SDG)s is to end poverty in all forms everywhere which includes income generation activity and skill development specifically for rural India [18]. The researcher was constantly working with the lotus cultivators. It was observed that lotus cultivators wanted to have new avenues for their cultivation. They are very interested and readily helped throughout the study and ready to be associated in future also.

Fabric produced from the lotus fiber has superior qualities like softness, fineness, light weight which can be used in many areas of textiles right from apparels especially for kids wear and technical textiles like medical textiles specially for hygiene products. A small scale industry can be developed for lotus fiber to fabric production.

\section{Acknowledgements}

The authors are thankful to Mrs. Shantaben Mali (Vendor, Lotus Flower), Mr. Poonambhai Parmar, Mr. Isabbhai Rathod and Sanjaybhai Mali (Cultivators of Lotus) near and around Vadodara district of Gujarat. The contribution of these peoples was the backbone for the research. Authors are also thankful to the peoples of Khadi Emporium and Mr. Bakul Shah (Member Sardar Bhavan trust), Vadodara for spinning of yarns. Thanks to Mr. Pachan bhai Premji, Weaver at Bhujodi, Kutch for weaving the fabric. 


\section{Bibliography}

1. Gopal B. "Wetland Conservation for Biodiversity and Ecosystem Sevices Needs as shift in Land and water resources policies". National Institute of Ecology, Delhi 1-16.

2. Mishra MK., et al. "Survey of useful wetland plants of South Odisha". India Indian Journal of Traditional Knowledge 11.4 (2012): 658-666.

3. Lin Z., et al. "The Latest Studies on Lotus (Nelumbo nucifera)an Emerging Horticultural Model Plant". International Journal of Molecular sciences 22.3680 (2019): 2-13.

4. Gardetti M and Muthu S. "Handbook of sustainable luxury textiles and fashion". Springer, Singapore 1 (2015): 59-98.

5. https://bsienvis.nic.in/files/National\%20Flower_Nelumbo\%20nucifera_26.9.14.pdf

6. https://www.dnaindia.com/ahmedabad/column-flowers-ofsome-wetland-plants-elegance-personified-2748658

7. Zaidi A and Srivastava AK. "Nutritional and Therapeutic importance of Nelumbo nucifera (Sacred Lotus)". Era's Journal of Medical Research 6.2 (2019): 1-5.

8. Matthews PGD and Seymour R. "Anatomy of gas canal system of Nelumbo nucifera”. Aquatic Botany (2006): 78-91.

9. ASTM D 7025-09. "e1: Standard Test method for assessing clean flax fiber fineness". ASTM International, West Conshohocken, PA (2015).

10. ASTM D3822-07. "Standard test method for tensile properties of single textile fibers". ASTM International, West Conshohocken, PA (2007).

11. Booth JE. "Principles of textile testing. CBS Publishers and distributors". Pvt. Ltd. New Delhi, India (1996): 100-230.

12. Gohl EPG and Vilensky LDT. "CBS Publishers and Distributors". Pvt Ltd. New Delhi India (1987).

13. https://www.knittingthenaturalway.com/fiber-diameters

14. https://dnfi.org/wp-content/uploads/2012/01/fact-sheetplant-fibers.pdf

15. https://www.textileschool.com/390/properties-of-vegetable-plant-cellulosic-fibres/
16. Textile Fibers Textile Technology Knowledge series, Texcoms textile Solutions (2019).

17. ASTM D 1909-04. Standard Table of Commercial Moisture Regains for Textile Fibers 1 West Conshohocken, PA (1961).

18. https://www.un.org/sustainabledevelopment/poverty/

19. http://kk-bhai.blogspot.com/2015/09/lotus-flower.html

20. Chen Y., et al. "Isolation and Characteristics of Cellulose and Nanocellulose from Lotus Leaf Stalk Agro-wastes". Bio - Resources 10.1 (2015): 684-696.

\section{Assets from publication with us}

- Prompt Acknowledgement after receiving the article

- Thorough Double blinded peer review

- Rapid Publication

- Issue of Publication Certificate

- High visibility of your Published work

Website: www.actascientific.com/

Submit Article: www.actascientific.com/submission.php Email us: editor@actascientific.com

Contact us: +919182824667 